\title{
Recurrent Respiratory Papillomatosis
}

National Cancer Institute

\section{Source}

National Cancer Institute. Recurrent Respiratory Papillomatosis. NCI Thesaurus. Code C128637.

A rare disease caused by the human papillomavirus (HPV), most commonly types 6 and 11 , that affects tissue along the respiratory tract with the majority of cases affecting the larynx. The disease has a bimodal distribution and manifests in those younger than age 5, juvenile-onset recurrent respiratory papillomatosis (JORRP), and those older than age 40, adult-onset recurrent respiratory papillomatosis (AORRP). JORRP is more common and more severe in presentation than AORRP. In a small percentage of patients, respiratory papillomas may undergo malignant transformation to squamous cell carcinomas that have a poor prognosis. 